\title{
RADIOCARBON IN THE AIR OF CENTRAL EUROPE: LONG-TERM INVESTIGATIONS
}

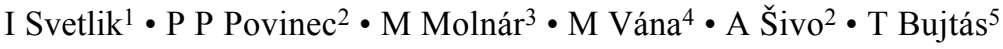 \\ ABSTRACT. Regional levels of radiocarbon have been monitored in order to investigate the impact of fossil fuel combus- \\ tion on the activity of atmospheric ${ }^{14} \mathrm{CO}_{2}$ in central Europe. Data from atmospheric ${ }^{14} \mathrm{CO}_{2}$ monitoring stations in the Czech \\ Republic, Slovakia, and Hungary for the period 2000-2008 are presented and discussed. The Prague and Bratislava monitor- \\ ing stations showed a distinct local Suess effect when compared to the Jungfraujoch clean-air monitoring station. However, \\ during the summer period, statistically insignificant differences were observed between the low-altitude stations and the high- \\ mountain Jungfraujoch station. ${ }^{14} \mathrm{C}$ data from the Hungarian monitoring locality at Dunaföldvár and the Czech monitoring \\ station at Košetice, which are not strongly affected by local fossil $\mathrm{CO}_{2}$ sources, indicate similar grouping and amplitudes, typ- \\ ical for a regional Suess effect.
}

\section{INTRODUCTION}

Radiocarbon is a long-lived radionuclide (half-life $5730 \mathrm{yr}$ ) of global occurrence produced either naturally or artificially. It is produced naturally by interactions of cosmic rays mainly with atmospheric nitrogen in the nuclear reaction ${ }^{14} \mathrm{~N}(\mathrm{n}, \mathrm{p}){ }^{14} \mathrm{C}$. The mean natural ${ }^{14} \mathrm{C}$ production rate is about 2.5 atoms cm$~_{-2} \mathrm{~s}^{-1}$ at the Earth's surface (UNSCEAR 2000). ${ }^{14} \mathrm{C}$ is subsequently oxidized to $\mathrm{CO}_{2}$, which is then transferred to the troposphere, where ${ }^{14} \mathrm{C}$ becomes a part of the carbon environmental cycle. Inorganic and organic chemical forms of ${ }^{14} \mathrm{C}$ are deposited into oceanic and terrestrial carbon reservoirs. Although the natural ${ }^{14} \mathrm{C}$ production and deposition rates have been relatively stable, the ${ }^{14} \mathrm{C}$ levels in the atmosphere and biosphere during the pre-industrial period showed multiple changes ("wiggles" in the ${ }^{14} \mathrm{C}$ calibration curve).

In the last century, nuclear weapons tests were important sources of anthropogenic ${ }^{14} \mathrm{C}$. Consequently, ${ }^{14} \mathrm{C}$ concentration in the atmosphere of the Northern Hemisphere was double the natural level in 1963 (Nydal and Lövseth 1965; Meijer et al. 1995). Since the nuclear moratorium on atmospheric nuclear bomb tests was signed in 1963 , the ${ }^{14} \mathrm{C}$ concentration in the atmosphere has been decreasing due to its intensive transfer to oceanic and terrestrial carbon reservoirs (Levin et al. 1980, 1995; Segl et al. 1983; Burchuladze et al. 1989; Hesshaimer et al. 1994; Levin and Kromer 1997, 2004). Currently, ${ }^{14} \mathrm{C}$ activity is gradually approaching the level that was seen before the nuclear age. The observed ${ }^{14} \mathrm{C}$ levels give information about carbon ${ }^{14} \mathrm{C}$ sinks and exchange processes (stratosphere-troposphere, troposphere-ocean, troposphere-biosphere mixing). The decreasing bomb ${ }^{14} \mathrm{C}$ curve has also been used for dating samples that originated during the nuclear period (Reimer et al. 2004).

In the last few decades, discharges from nuclear facilities (nuclear fuel reprocessing and nuclear power plants) have also been a significant artificial source of ${ }^{14} \mathrm{C}$. Their contributions have been estimated to be $\sim 10 \%$ of natural production (UNSCEAR 2000). These releases have been increasing ${ }^{14} \mathrm{C}$ concentration in the atmosphere, and several studies have been devoted to investigating local anthropogenic effects (Chudy and Povinec 1982; Kunz 1985; Cimbák et al. 1986; McCartney et al.

\footnotetext{
${ }^{1}$ Department of Radiation Dosimetry, Nuclear Physics Institute AS CR, Na Truhlarce 39/64, CZ-180 86 Prague, Czech Republic. Corresponding author. Email: svetlik@ujf.cas.cz.

${ }^{2}$ Faculty of Mathematics, Physics and Informatics, Comenius University, SK-842 48 Bratislava, Slovakia.

${ }^{3}$ Institute of Nuclear Research of the Hungarian Academy of Sciences (ATOMKI), Bem tér 18/c, 4026 Debrecen, Hungary.

${ }^{4}$ Czech Hydrometeorological Institute, CZ-394 22 Košetice Observatory, Czech Republic.

${ }^{5}$ Paks nuclear power plant, Paks, Hungary.
}

(C) 2010 by the Arizona Board of Regents on behalf of the University of Arizona Proceedings of the 20th International Radiocarbon Conference, edited by A J T Jull RADIOCARBON, Vol 52, Nr 2-3, 2010, p 823-834 
1986; Obelić et al. 1986; Povinec et al. 1986a,b, 2008; Levin et al. 1988; Hertelendi et al. 1989b; Loosli and Oeschger 1989; Otlet et al. 1990; Uchrin et al. 1992, 1998; Milton et al. 1995; RousselDebet et al. 2006).

There is another significant anthropogenic influence on ${ }^{14} \mathrm{C}$ levels in the atmosphere and biosphere, the Suess effect (Suess 1955; Burchuladze et al. 1980; Segl et al. 1983; Levin et al. 1995, 2003; Kuc and Zimnoch 1998; Levin and Hesshaimer 2000). This effect causes a relative decrease of the ${ }^{14} \mathrm{C}$ activity on global, regional, and local scales as a result of the dilution of the carbon isotopic mixture by fossil carbon. ${ }^{14} \mathrm{C}$ monitoring continental stations might shed more light on the (spatial and temporal) distribution of fossil fuel emissions, mainly by providing information about summer versus winter ${ }^{14} \mathrm{C}$ levels in comparison with "nearby" background (clean-air) sampling stations (Levin et a1. 1988; Meijer et al. 1995).

\section{SAMPLES AND METHODS}

Samples of atmospheric ${ }^{14} \mathrm{CO}_{2}$ have been collected in 1-month periods at 4 localities in central Europe (see Figure 1). The intentions of monitoring were the following (Svetlik et al. 2006; Molnár et al. 2007):

1. To determine ${ }^{14} \mathrm{C}$ reference levels in the environment and their seasonal and annual changes in locations with lesser (Košetice, Dunaföldvár) and greater (Prague, Bratislava) local anthropogenic influences.

2. To find robust ${ }^{14} \mathrm{C}$ reference parameters, which are minimally influenced by the Suess effect, e.g. spring/summer ${ }^{14} \mathrm{CO}_{2}$ activities, or activity concentrations of atmospheric ${ }^{14} \mathrm{CO}_{2}$ in air in the relation to the Suess effect (Svetlik et al. 2010).

3. To provide corrections for ${ }^{14} \mathrm{C}$ dating of various types of samples originating after 1960 (e.g. utilizing CaliBomb, http://intcal.qub.ac.uk/CALIBomb/). It can be expected that many of the samples will come from areas affected by a local and regional Suess effect.

\section{Czech Republic (CZ)}

Monitoring of atmospheric ${ }^{14} \mathrm{CO}_{2}$ at the Prague-Bulovka $\left(50^{\circ} 07^{\prime} \mathrm{N}, 14^{\circ} 27^{\prime} \mathrm{E}\right)$ site began in 2001. This site is near the border of the urban agglomeration of Prague, in the vicinity of a heavily used motorway; therefore, a local load from fossil fuel combustion can be expected there. The second monitoring station was launched in 2004 at the Košetice Meteorological Observatory $\left(49^{\circ} 35^{\prime} \mathrm{N}\right.$, $15^{\circ} 05^{\prime} \mathrm{E}$; a part of the Czech Hydrometeorological Institute), which is situated in the Czech-Moravian Highlands. The surroundings of this site have an agricultural-forestry character, without significant local sources of fossil $\mathrm{CO}_{2}$.

Monthly $\mathrm{CO}_{2}$ samples were collected by bubbling the air through a $0.7 \mathrm{M} \mathrm{NaOH}$ solution in $1.9-\mathrm{L}$ flasks (the final amount of carbonates did not exceed $30 \%$ of the saturation capacity of the solution) located at the Prague-Bulovka and Košetice sampling stations. The samples were processed by acid carbonate decomposition, $\mathrm{CO}_{2}$ purification, benzene preparation, and measurement by a low-background liquid scintillation spectrometer, Quantulus 1220 $0^{\mathrm{TM}}$ (Svetlik et al. 2006; Molnár et al. 2007). For calibration purposes, oxalic acid NIST (National Institute of Standards and Technology, Gaithersburg, USA) SRM 4990C, has been used. A few $\mathrm{mL}$ of exposed $\mathrm{NaOH}$ solution, collected from samples, were analyzed using a stable isotope mass spectrometer for determination of the ${ }^{13} \mathrm{C} /{ }^{12} \mathrm{C}$ isotopic ratio. Measured data were statistically evaluated and the resulting ${ }^{14} \mathrm{CO}_{2}$ activities were $\delta^{13} \mathrm{C}$-corrected and reported as $\Delta^{14} \mathrm{C}$ following Stuiver and Polach (1977). 


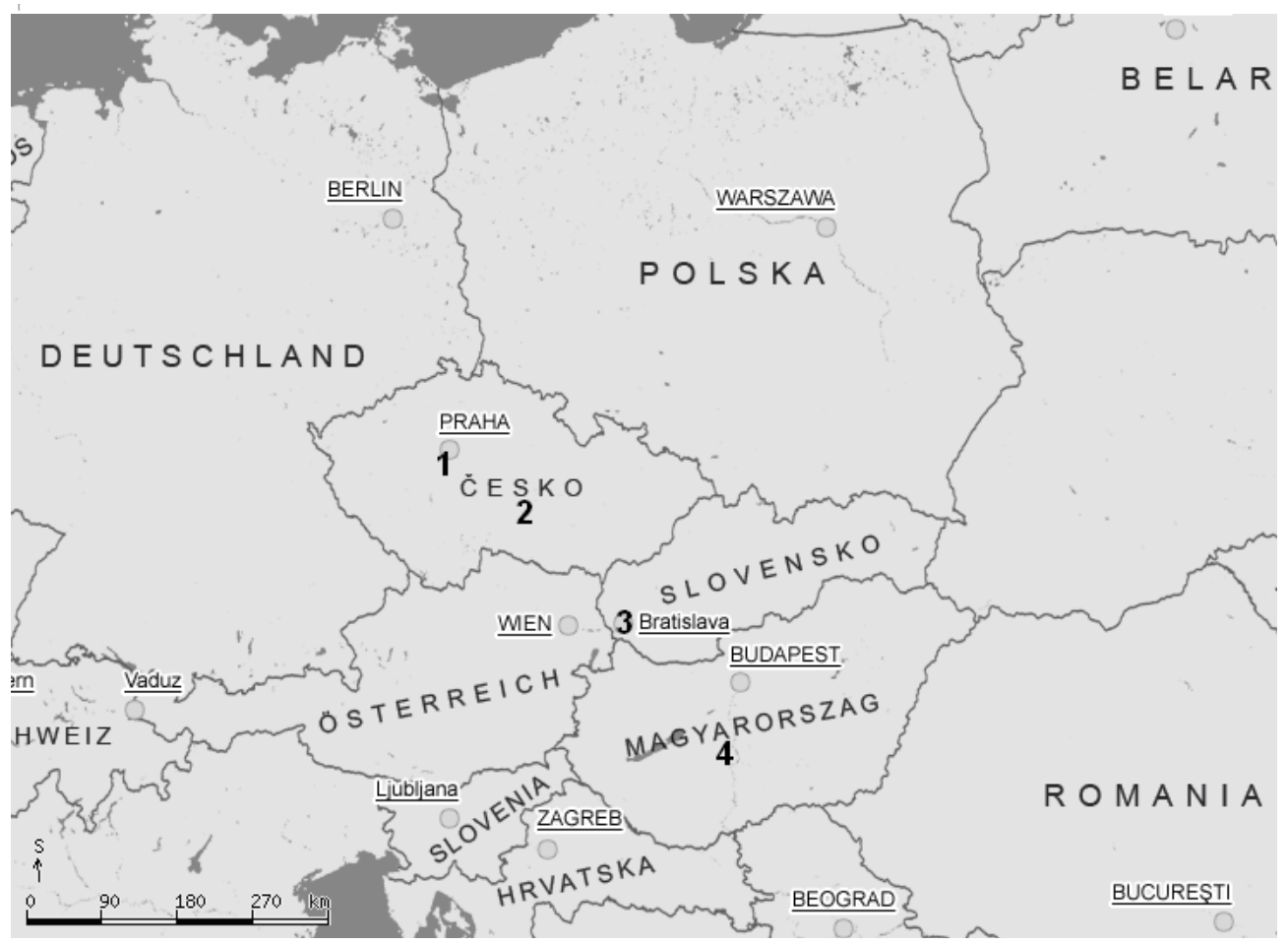

Figure $1{ }^{14} \mathrm{CO}_{2}$ sampling stations in the Czech Republic (1 and 2), Slovakia (3), and Hungary (4)

\section{Slovakia (SK)}

Samples in Bratislava were collected on the roof of the Physics building, which has been situated in the center of the town since 1967 (Povinec et al. 1968; Usačev et al. 1973). Since 1975, samples of $\mathrm{CO}_{2}$ in Bratislava air were collected on the roof ( $\sim 15 \mathrm{~m}$ above the ground) of the Physics building at the new University campus at Mlynská dolina $\left(48^{\circ} 09^{\prime} \mathrm{N}, 17^{\circ} 07^{\prime} \mathrm{E}\right)$, about $3 \mathrm{~km}$ from downtown. The campus is situated on a small hill about $164 \mathrm{~m}$ asl. Bratislava, with almost 500,000 inhabitants, represents an industrialized region that is expected to be influenced by fossil fuel $\mathrm{CO}_{2}$ emissions, mainly from cars and fossil fuel energy sources. Since 1987, samples of atmospheric $\mathrm{CO}_{2}$ were collected by bubbling the air through two 2.5 -L flasks filled with $0.5 \mathrm{M} \mathrm{NaOH}$ solution in 1-month periods (the final amount of carbonates did not exceed $54 \%$ of the saturation capacity of the solution). The sample from the exposed solution was precipitated as $\mathrm{BaCO}_{3}$, and $\mathrm{CO}_{2}$ was liberated in a vacuum line by adding $\mathrm{H}_{3} \mathrm{PO}_{4}$. The amount of $\mathrm{CO}_{2}$ gas was measured volumetrically in a calibrated volume. Further, $\mathrm{CH}_{4}$ was prepared from the $\mathrm{CO}_{2}$ sample (Povinec 1972) for filling the low-level proportional counter, which was used for counting ${ }^{14} \mathrm{C}$ decays (Povinec 1978). A few $\mathrm{mL}$ of $\mathrm{CO}_{2}$ collected from samples were analyzed using a stable isotopic mass spectrometer for determination of the ${ }^{13} \mathrm{C} /{ }^{12} \mathrm{C}$ isotopic ratio. ${ }^{14} \mathrm{C}$ results are presented as $\Delta{ }^{14} \mathrm{C}$ values (standard deviations $\pm 5 \%$ ) relative to the NIST oxalic acid standard SRM 4990C, and corrected for isotopic fractionation according to convention (Stuiver and Polach 1977).

\section{Hungary (H)}

The excess of ${ }^{14} \mathrm{C}$ in ${ }^{14} \mathrm{CO}_{2}$ and ${ }^{14} \mathrm{CH}_{4}$ chemical forms has been measured in Hungary in the vicinity of the Paks nuclear power plant (NPP) by sampling environmental air since 1991 (Veres et al. 1995). 
However, for this work, we used data from another Hungarian sampling site, situated near Dunaföldvár city $\left(46^{\circ} 47^{\prime} \mathrm{N}, 18^{\circ} 57^{\prime} \mathrm{E}\right)$, which has been used as a reference environmental monitoring station since 1996. The station is located about $20 \mathrm{~km}$ north of the NPP in an agricultural area (Molnár et al. 2007).

${ }^{14} \mathrm{C}$ was collected in the form of $\mathrm{CO}_{2}$ by bubbling the air through 0.6 - $\mathrm{L}$ flasks filled with $0.4 \mathrm{~L}$ of $3 \mathrm{M}$ $\mathrm{NaOH}$ solution (the final amount of carbonates did not exceed $15 \%$ of the saturation capacity of the solution). To extract $\mathrm{CO}_{2}$ from the samples, concentrated (75\%) sulfuric acid was added to the $\mathrm{NaOH}$ solution. The liberated $\mathrm{CO}_{2}$ was purified over charcoal, then frozen into a $\mathrm{CO}_{2}$ trap with liquid nitrogen at $-196^{\circ} \mathrm{C}$, and the remaining non-condensable components were removed by a vacuum pump. The activity of the samples was measured using a gas proportional counter (Csongor et al. 1982; Csongor and Hertelendi 1986; Hertelendi et al. 1989a; Molnár et al. 2010). The standard deviation of a single $\Delta^{14} \mathrm{C}$ measurement applying this method was $\pm 5 \%$ (Hertelendi 1990). $\delta^{13} \mathrm{C}$ corrections were measured by a stable isotope mass spectrometer. $\delta^{13} \mathrm{C}$-corrected $\Delta^{14} \mathrm{C}$ data are given relative to the NIST SRM 4990 (oxalic acid) standard (Stuiver and Polach 1977).

\section{RESULTS}

Figure 2 shows the $\Delta^{14} \mathrm{C}$ results from monitoring stations in the Czech Republic, Slovakia, and Hungary. For comparison, data from Jungfraujoch (JFJ) in Switzerland, a high-mountain background (clean-air) monitoring station with only a global Suess effect, are also included (Levin and Kromer 2004; Levin et al. 2008). For estimation of the anthropogenic impact from a local and regional Suess effect, a difference between the Jungfraujoch monitoring station and a local monitoring station was calculated according to the formula:

$$
S_{l+r}=\frac{a_{J F}-a_{o b s}}{1+0.001 \cdot a_{J F}}[\% 0]
$$

where $S_{l+r}$ is the local and regional Suess effect (reported in per mil of fossil contribution in the carbon isotopic mixture), $a_{J F}$ is the fit with harmonics for the seasonal cycle of the reference ${ }^{14} \mathrm{C}$ activity measured in the Jungfraujoch monitoring station, and $a_{o b s}$ is the value observed in a given monitoring station (Nakazawa et al. 1997; Svetlik et al. 2006; Levin et al. 2008). All activities utilized in this formula are given in per mil of $\Delta^{14} \mathrm{C}$ (Stuiver and Polach 1977). Diagrams of the calculated local and regional Suess effect together with mean monthly temperatures are shown in Figure 3.

A local Suess effect may be important in urban areas, in the vicinity of motorways, coal electric power, or heat plants, etc. A regional Suess effect may be prevailing only in areas without the presence of greater local fossil carbon sources, where the local Suess effect is minimal. If relevant reference data from a monitoring station charged predominantly by regional Suess effect are available, a local Suess effect for bigger fossil carbon sources, such as urban areas, can be estimated using a similar formula:

$$
S_{l}=\frac{a_{r e g}-a_{o b s}}{1+0.001 \cdot a_{J F}}[\% 0]
$$

where $\mathrm{S}_{l}$ is the local Suess effect (reported in per mil of fossil contribution in the carbon isotopic mixture), and $a_{r e g}$ is the regional reference activity observed in the corresponding location where local sources of fossil carbon can be neglected (Svetlik et al. 2006). To minimize distortions given by different atmospheric conditions, the time behavior of mean monthly temperature data should be similar in the regional reference monitoring station and in the compared locality. Similarly as for 

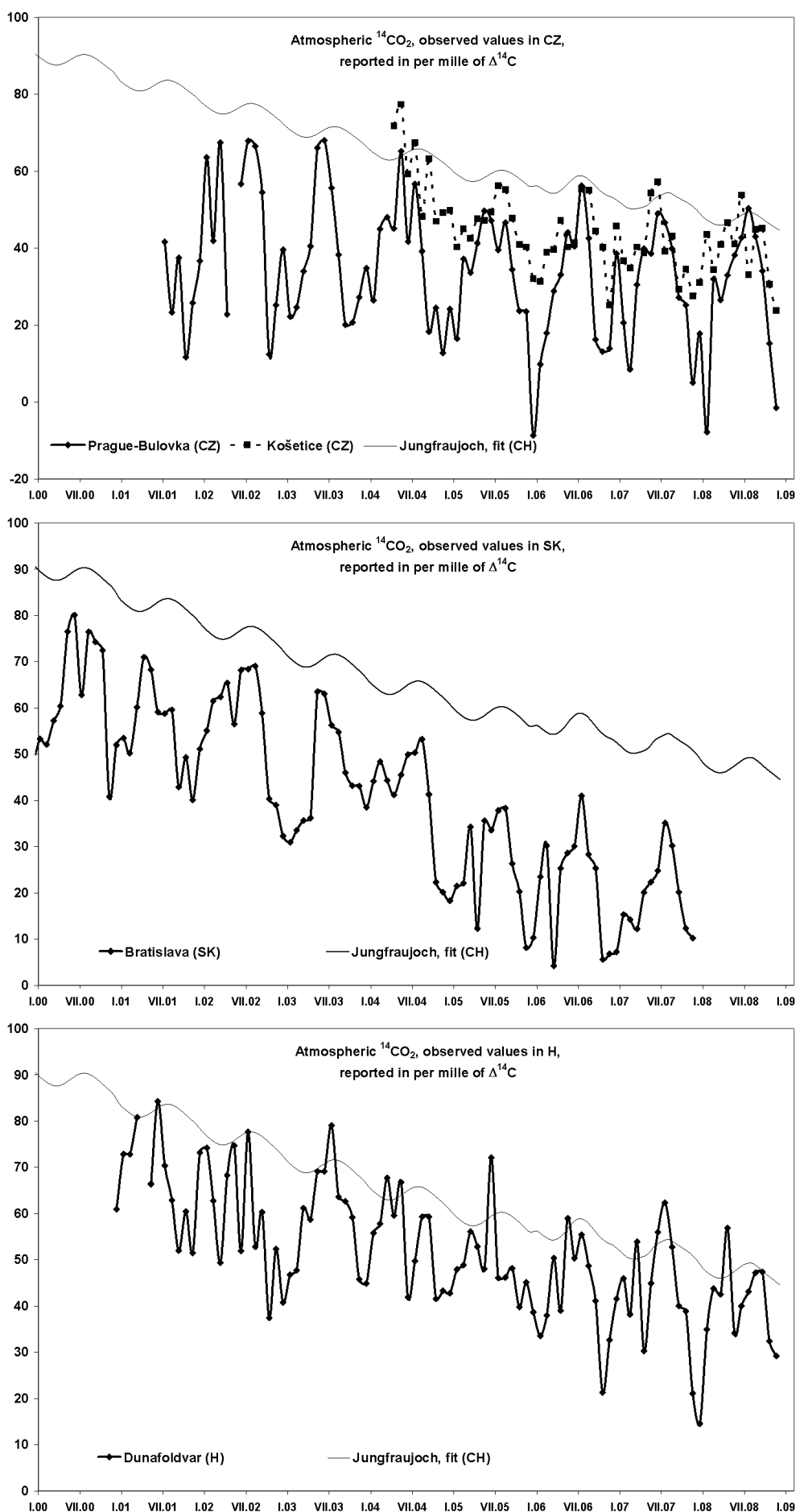

Figure 2 Atmospheric ${ }^{14} \mathrm{CO}_{2}$ levels in the Czech Republic (a), Slovakia (b), and Hungary (c), compared with the Jungfraujoch Alpine (clean-air) station. 

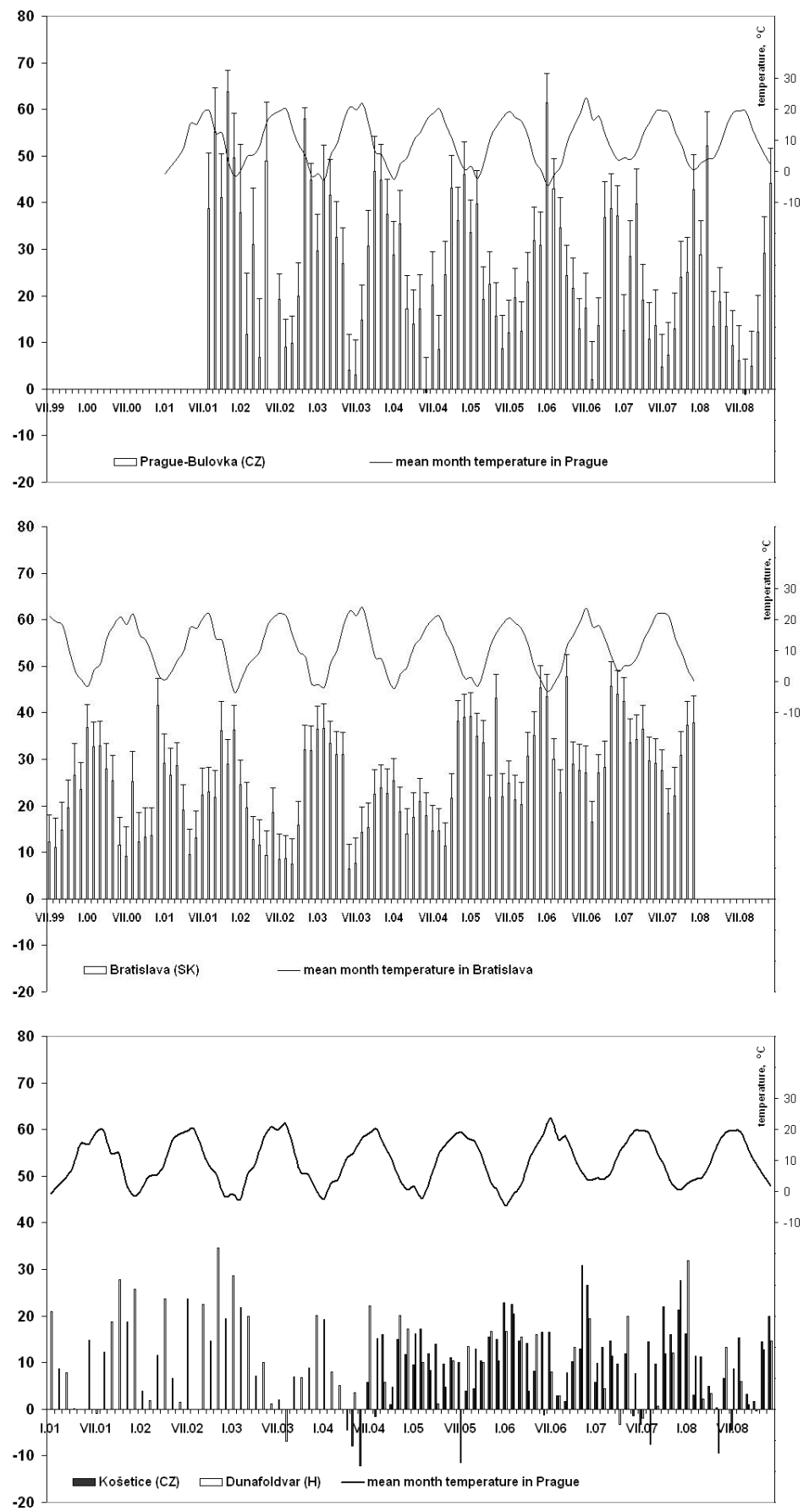

Figure 3 Local and regional Suess effect $S_{l+r}$ in the Prague-Bulovka (a), Bratislava (b), and Dunafoldvár and Košetice stations with similar time behavior given by prevailing regional Suess effect (c), calculated using the Jungfraujoch (JFJ) harmonic fit as reference values (Levin and Kromer 2004; Levin et al. 2008). Data reported in \%o of fossil C amount from local and regional sources in carbon isotopic mixture. 
$S_{l+r}$ the local Suess effect is normalized to the $a_{J F}$ value (supposing that $\mathrm{S}_{l}$ is a part of $S_{l+r}$ observed in a given site). Using the data presented here, the local Suess effect for the Prague-Bulovka site can be calculated using regional reference values from the Košetice monitoring station (Figure 4). The seasonal cycles of the regional reference data have significantly larger amplitudes than those observed at the JFJ station; hence, most of the time, the high Alpine monitoring station at Jungfraujoch is sampling free tropospheric air (Levin and Kromer 2004; Meijer et al. 2006).

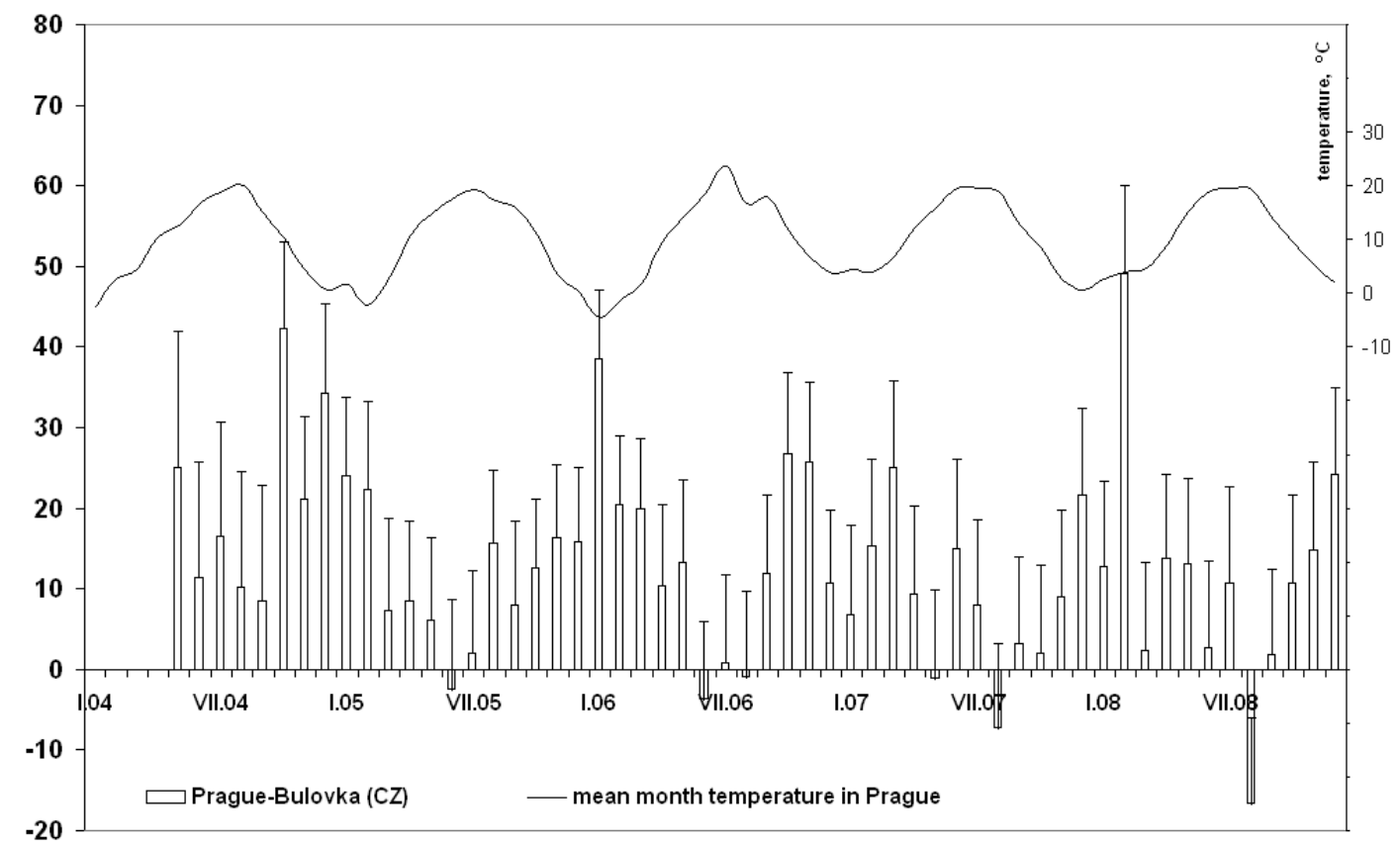

Figure 4 Local Suess effect $S_{1}$ in the monitoring area Prague-Bulovka, calculated using the Košetice data as reference regional values. Reported in \%o of fossil C amount from local sources in carbon isotopic mixture.

\section{DISCUSSION}

The time behavior of observed ${ }^{14} \mathrm{C}$ activities from the monitoring localities demonstrates seasonal changes and a gradual interannual decrease (Figure 2). The most distinct seasonal changes are observed in both urban monitoring localities at Prague-Bulovka and Bratislava-Mlynská dolina, where a strong local impact from fossil fuel combustion is expected. The resulting ${ }^{14} \mathrm{C}$ concentrations at Dunaföldvár are similar to those observed at Košetice, where the local Suess effect is expected to be negligible. The amplitudes of seasonal changes in Dunaföldvár and Košetice are similar; however, they are considerably greater than variations observed at the Jungfraujoch monitoring station.

The time behavior of calculated values $\mathrm{S}_{l+r}$ for each locality and $S_{l}$ for the Prague-Bulovka station highlights seasonal changes, with maximum values during winter (Figures 3 and 4). Emissions of fossil carbon were amplified by abundant occurrence of atmospheric inversions that occurred during the winter months. A lack of atmospheric mixing during an inversion has a much larger influence on the ${ }^{14} \mathrm{C}$ signal (as well as on the $\mathrm{CO}_{2}$ concentration) than an increase of fossil $\mathrm{CO}_{2}$ emissions during winter as a result of enhanced heating. This effect is clearly visible in the diurnal cycle, but also in the seasonal cycle. This implies that the seasonal effect is much less sensitive to $\mathrm{CO}_{2}$ fossil sources and sinks (photosynthesis) in summer than in winter. This effect is called the "seasonal rectifier effect" (Denning et al. 1999; Palstra et al. 2008). 
A comparison with the temperature curve shows that a small fossil carbon asymmetry between the spring and autumn parts seems to be visible, although the temperatures are similar. This effect may be connected with modestly different conditions for fossil $\mathrm{CO}_{2}$ dissipation in the atmosphere during spring and autumn. The $S_{l+r}$ values observed in the urban Prague-Bulovka site have the greatest amplitudes, which are connected with minimum temperatures. By contrast, the time behavior of greater values of the Suess effect in the urban Bratislava-Mlynská dolina station has a longer duration during each year. Such a dissimilarity could be caused by different dissipation conditions in the surroundings of the Bratislava-Mlynská dolina monitoring station and also partly by higher seasonal stability of fossil $\mathrm{CO}_{2}$ sources (Povinec et al. 2009). In both urban localities, with larger loads from fossil fuel combustion, the observed Suess effect values $\left(S_{l+r}\right)$ seem to be close to or below the significance level during the summer period (i.e. June-July), although frequently motorways, which are relatively stable sources of fossil carbon throughout the year, are situated in the vicinity of these sampling stations (Povinec et al. 2008).

If the data of the $\mathrm{CO}_{2}$ mixing ratio are absent when calculating fossil $\mathrm{CO}_{2}$ concentration (in ppm), there is the possibility of calculating the local and regional Suess effect $S_{l+r}$, corresponding to a percentage (per mil) of fossil carbon amount in the carbon isotopic mixture (from local and regional sources). Using $S_{l+r}$ values, corrections for ${ }^{14} \mathrm{C}$ activity influenced by fossil carbon sources can be estimated (see Figure 5). Mean monthly values of $S_{l+r}$ from both urban (Prague and Bratislava) and both regional sites (Košetice and Dunaföldvár) were statistically compared (Table 1, paired $t$ test, $\alpha=0.05,\left|t_{\text {obs }}\right|<t_{\text {crit }}=>\mu_{1}=\mu_{2}$ ) and mean values for "cities" and "regions" were subsequently calculated (see Table 2).

Table 1 Statistical comparison of mean monthly $S_{1+r}$ values for monitoring stations Prague-Bulovka, Bratislava-Mlynská dolina, Košetice, and Dunaföldvár (calculated according to Goulden [1956]).

\begin{tabular}{lcl} 
& Prague-Bulovka & Bratislava-Mlynská dolina \\
\hline Mean $(\mu)$ & 25.51 & 25.56 \\
Variance $\left(\delta^{2}\right)$ & 131.15 & 47.57 \\
Minimum & 8.0 & 17.2 \\
Maximum & 41.6 & 37.3 \\
Number of observations & 12 & 12 \\
2-sample paired $t$ test for equal means, $\alpha=0.05$ & \\
$\left|t_{\text {obs }}\right|$ & & 0.0300 \\
Critical value for $t$ (bilateral) & Košetice & 2.2010 \\
\hline & 10.12 & Dunaföldvár \\
\hline Mean $(\mu)$ & 22.72 & 10.62 \\
Variance $\left(\delta^{2}\right)$ & 4.2 & 31.03 \\
Minimum & 18.9 & 4.0 \\
Maximum & 12 & 19.3 \\
Number of observations & $\alpha=0.05$ & 12 \\
2-sample paired $t$ test for equal means, & \\
$\left|t_{\text {obs }}\right|$ & & 0.4885 \\
Critical value for $t$ (bilateral) & & 2.2010 \\
\hline
\end{tabular}

If we want to apply the $S_{l+r}$ corrections for dating of samples originating in the last decades, the investigated samples should originate from areas with similar loads from fossil fuel combustion. Such corrections will also depend on a sample ingrowth period. For samples with ingrowth during summer months, such a correction can be insignificant, as evident from $S_{l+r}$ seasonal courses (see Figures 3 and 5). In the case of a continual sample accumulation throughout the year (e.g. into car- 
Table 2 Calculated mean values of $S_{l+r}$ for sites with prevailing regional Suess effect (Dunaföldvár and Košetice) and in urban areas (Prague-Bulovka and Bratislava-Mlyská dolina).

\begin{tabular}{llll|lll}
\hline & \multicolumn{3}{c|}{ Urban areas } & \multicolumn{3}{c}{ Regional sites } \\
\cline { 2 - 7 } Month & $\begin{array}{l}\text { Average } \\
\text { value }\end{array}$ & $\begin{array}{l}\text { Standard } \\
\text { deviation }\end{array}$ & $\begin{array}{l}\text { Nr of } \\
\text { observations }\end{array}$ & $\begin{array}{l}\text { Average } \\
\text { value }\end{array}$ & $\begin{array}{l}\text { Standard } \\
\text { deviation }\end{array}$ & $\begin{array}{l}\text { Nr of } \\
\text { observations }\end{array}$ \\
\hline I & 34.0 & 11.0 & 15 & 16.8 & 8.6 & 12 \\
II & 32.6 & 10.6 & 15 & 11.9 & 7.3 & 12 \\
III & 27.3 & 9.8 & 15 & 11.2 & 4.9 & 12 \\
IV & 23.4 & 10.4 & 15 & 6.2 & 8.1 & 12 \\
V & 23.5 & 11.8 & 15 & 6.1 & 8.7 & 12 \\
VI & 13.9 & 8.5 & 14 & 5.7 & 8.3 & 12 \\
VII & 15.1 & 8.5 & 15 & 5.8 & 10.5 & 13 \\
VIII & 15.1 & 9.7 & 16 & 5.4 & 8.1 & 13 \\
IX & 18.9 & 12.1 & 16 & 8.6 & 7.1 & 13 \\
X & 27.9 & 10.6 & 16 & 10.3 & 8.1 & 13 \\
XI & 36.4 & 12.5 & 16 & 17.6 & 7.4 & 13 \\
XII & 39.5 & 6.8 & 16 & 19.2 & 5.4 & 13 \\
\hline
\end{tabular}

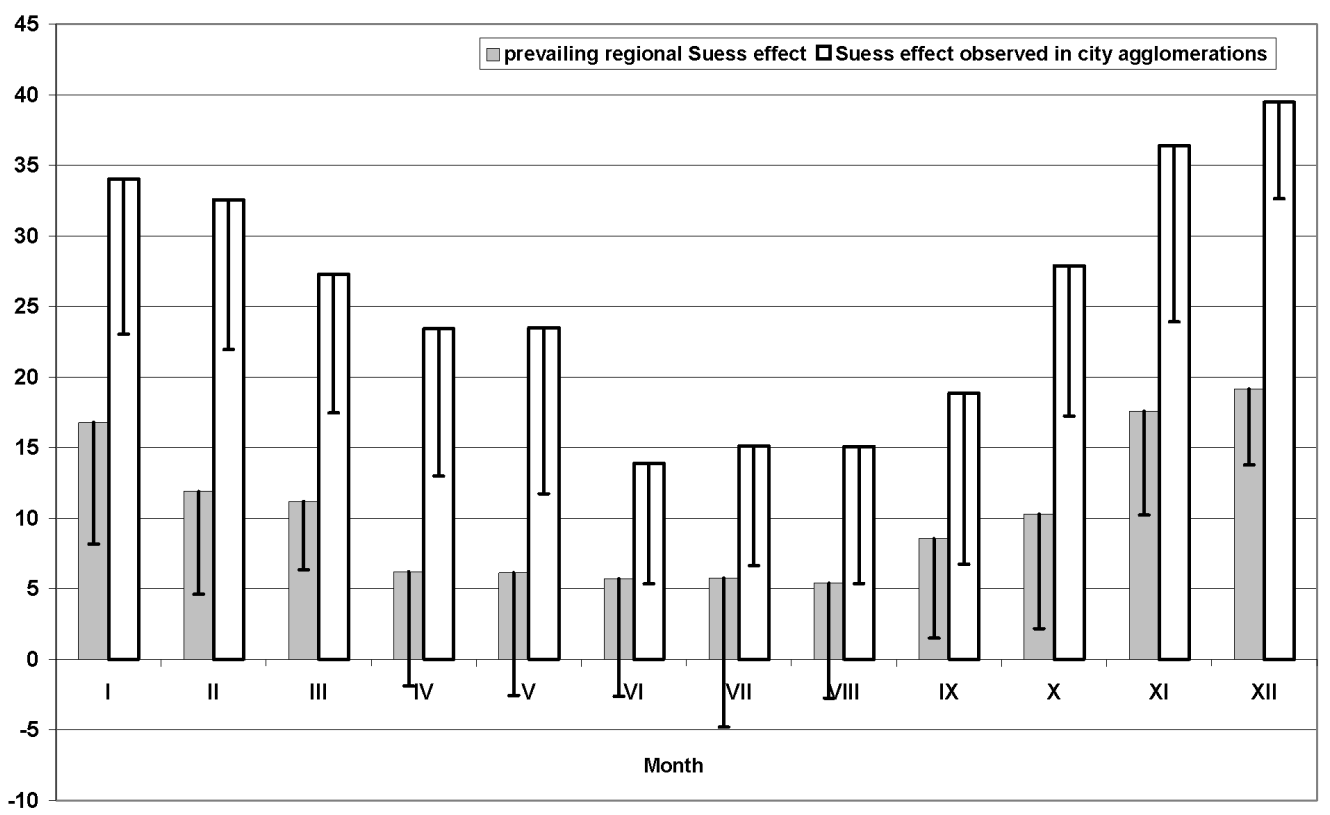

Figure 5 Calculated mean monthly values of $S_{l+r}$ for sites with prevailing regional Suess effect (Dunaföldvár and Košetice) and in urban areas (Prague-Bulovka and Bratislava-Mlyská dolina). The average ratio of $S_{1+r}$ in cities to regional reference sites is $2.64 \pm 0.61$, ranging from 2.0 (January) to 3.8 (April and May).

bonate layers), it can be beneficial to estimate the connected uncertainty and to calculate a Suess effect correction (see Table 2). In the case of a uniform sample ingrowth, an annual mean value can be applied. In the opposite case, the weighted mean value can be estimated if changes in a sample accumulation rate during the season are known. 


\section{CONCLUSIONS}

The results of atmospheric ${ }^{14} \mathrm{CO}_{2}$ monitoring carried out in the Czech Republic, Slovakia, and Hungary showed that at the Prague-Bulovka and Bratislava-Mlynská dolina monitoring stations, a distinct local Suess effect was observed when compared to the values observed at the Jungfraujoch background monitoring station. This effect has a distinct seasonal behavior. Nevertheless, during the summer period (June to August), small differences were observed between the low-altitude stations and the high Alpine Jungfraujoch station, which is supposed to be minimally affected by local fossil fuel combustion in Europe. The data from the Hungarian monitoring station at Dunaföldvár and the Czech station at Košetice indicate similar grouping and amplitudes, which seems typical for the regional Suess effect.

In general, on the basis of our data it appears that values of $\Delta^{14} \mathrm{C}$ in the summer period are minimally charged by a local and regional Suess effect, even in the sites with relatively intensive local fossil fuel combustion due to better atmospheric mixing. ${ }^{14} \mathrm{C}$ activities during summer are close to Jungfraujoch values with interannual changes corresponding to a linear decrease in the last few years.

From the point of view of ${ }^{14} \mathrm{C}$ dating utilizing a bomb-peak curve, in the areas with greater sources of fossil $\mathrm{CO}_{2}$ (e.g. from combustion of natural gas, gasoline, oil, and coal) an influence of the local and regional Suess effect can be more significant in the case of relatively uniform yearly carbon accumulation (carbonates) than in the case of samples accumulating carbon mainly during the summer period (biota).

\section{ACKNOWLEDGMENTS}

This study was partially supported by the International Atomic Energy Agency, the Scientific Grant Agency of the Slovak Republic VEGA (project No. 1/108/08), institutional funding of Nuclear Physics Institute AS CR (AV0Z 10480505), and by funding of the State Office for Nuclear Safety of the Czech Republic (SUJB 3/2006).

\section{REFERENCES}

Burchuladze AA, Pagava SV, Povinec P, Togonidze GI, Usačev S. 1980. Radiocarbon variations with the 11year solar cycle during the last century. Nature 287(5780):320-2.

Burchuladze AA, Chudy M, Eristavy IV, Pagava SV, Povinec P, Šivo A, Togonidze GI. 1989. Anthropogenic ${ }^{14} \mathrm{C}$ variations in atmospheric $\mathrm{CO}_{2}$ and wines. Radiocarbon 31(3):771-6.

Chudy M, Povinec P. 1982. Radiocarbon production in $\mathrm{CO}_{2}$ coolant of a nuclear reactor. Acta Universitatis Comenianae, Physica 22:127-31.

Cimbák Š, Čechová A, Grgula M, Povinec P, Šivo A. 1986. Anthropogenic radionuclides ${ }^{3} \mathrm{H},{ }^{14} \mathrm{C},{ }^{85} \mathrm{Kr}$, and ${ }^{133} \mathrm{Xe}$ in the atmosphere around nuclear power reactors. Nuclear Instruments and Methods in Physics Research B 17(5-6):560-3.

Csongor É, Hertelendi E. 1986. Low-level counting facility for ${ }^{14} \mathrm{C}$ dating. Nuclear Instruments and Methods in Physics Research B 17(5-6):493-5.

Csongor É, Szabó I, Hertelendi E. 1982. Preparation of counting gas of proportional counters for radiocarbon dating. Radiochemical and Radioanalytical Letters 55:303-7.
Denning AS, Takahashi T, Friedlingstein P. 1999. Can a strong atmospheric $\mathrm{CO}_{2}$ rectifier effect be reconciled with a "reasonable" carbon budget? Keynote Perspective. Tellus B 51(2):249-53.

Goulden CH. 1956. Methods of Statistical Analysis. 2nd edition. New York: Wiley. p 50-55.

Hertelendi E. 1990. Sources of random error in the Debrecen radiocarbon laboratory. Radiocarbon 32(3): 283-7.

Hertelendi E, Csongor É, Záborszky L, Molnár J, Gál J, Györffi M, Nagy S. 1989a. A counter system for highprecision ${ }^{14} \mathrm{C}$ dating. Radiocarbon 31(3):399-406.

Hertelendi E, Uchrin G, Ormai P. 1989b. ${ }^{14} \mathrm{C}$ releases in various chemical forms with gaseous effluents from the Paks nuclear power plant. Radiocarbon 31(3): 754-61.

Hesshaimer V, Heimann V, Levin I. 1994. Radiocarbon evidence for a smaller oceanic carbon dioxide sink than previously believed. Nature 370(6486):201-3.

Kuc T, Zimnoch M. 1998. Changes of the $\mathrm{CO}_{2}$ sources and sinks in a polluted urban area (southern Poland) over the last decade, derived from the carbon isotope composition. Radiocarbon 40(1):417-23. 
Kunz C. 1985. Carbon-14 discharge at three light-water reactors. Health Physics 49(1):25-35.

Levin I, Hesshaimer V. 2000. Radiocarbon-a unique tracer of global carbon cycle dynamics. Radiocarbon 46(1):69-80.

Levin I, Kromer B. 1997. Twenty years of high-precision atmospheric ${ }^{14} \mathrm{CO}_{2}$ observations at Schauinsland station, Germany. Radiocarbon 39(2):205-18.

Levin I, Kromer B. 2004. The tropospheric ${ }^{14} \mathrm{CO}_{2}$ level in mid-latitudes of the Northern Hemisphere (19592003). Radiocarbon 46(3):1261-72.

Levin I, Münnich KO, Weiss W. 1980. The effect of anthropogenic $\mathrm{CO}_{2}$ and ${ }^{14} \mathrm{C}$ sources on the dilution of ${ }^{14} \mathrm{C}$ in atmosphere. Radiocarbon 22(2):379-81.

Levin I, Kromer B, Barabas M, Münnich KO. 1988. Environmental distribution and long-term dispersion of reactor ${ }^{14} \mathrm{CO}_{2}$ around two German nuclear power plants. Health Physics 54:149-56.

Levin I, Graul R, Trivett NBA. 1995. Long-term observations of atmospheric $\mathrm{CO}_{2}$ and carbon isotopes at continental sites in Germany. Tellus B 47:23-34.

Levin I, Kromer B, Schmidt M, Sartorius H. 2003. A novel approach for independent budgeting of fossil fuel $\mathrm{CO}_{2}$ over Europe by ${ }^{14} \mathrm{CO}_{2}$ observations. Geophysical Research Letters 30(23):2194, doi:10.1029/ 2002GL018477.

Levin I, Hammer S, Kromer B, Meinhardt F. 2008. Radiocarbon observations in atmospheric $\mathrm{CO}_{2}$ : determining fossil fuel $\mathrm{CO}_{2}$ over Europe using Jungfraujoch observations as background. Science of the Total Environment 391(2-3):211-6.

Loosli $\mathrm{HH}$, Oeschger H. 1989. ${ }^{14} \mathrm{C}$ in the environment of Swiss nuclear installations. Radiocarbon 31(3):74753.

McCartney P, Baxter MS, McKay K, Scott EM. 1986. Global and local effects of ${ }^{14} \mathrm{C}$ discharges from the nuclear fuel cycle. Radiocarbon 28(2A):634-43.

Meijer HAJ, van der Plicht J, Gislefoss JS, Nydal R. 1995. Long-term atmospheric records near Groningen, Fruholmen, and Izaña. Radiocarbon 37(1):3950 .

Meijer HAJ, Pertuisot MH, van der Plicht J. 2006. Highaccuracy ${ }^{14} \mathrm{C}$ measurements for atmospheric $\mathrm{CO}_{2}$ samples by AMS. Radiocarbon 48(3):355-72.

Milton GM, Kramer SJ, Brown RM, Repta CJW, King KJ, Rao RR. 1995. Radiocarbon dispersion around Canadian nuclear facilities. Radiocarbon 37(2):48596.

Molnár M, Bujtás T, Svingor É, Futó I, Svetlik I. 2007. Monitoring of atmospheric excess ${ }^{14} \mathrm{C}$ around Paks nuclear power plant, Hungary. Radiocarbon 49(2): 1031-43.

Molnár M, Haszpra L, Svingor É, Major I, Svetlik I. 2010. Atmospheric fossil fuel $\mathrm{CO}_{2}$ measurement using a field unit in a central European city during the winter of 2008/09. Radiocarbon 52(2-3):835-45.

Nakazawa T, Ishizawa M, Higuchi K, Trivett NBA.
1997. Two curve fitting methods applied to $\mathrm{CO}_{2}$ flask data. EnvironMetrics 8(3):197-218.

Nydal R, Lövseth K. 1965. Distribution of radiocarbon from nuclear tests. Nature 206(4988):1029-31.

Obelić B, Krajcar-Bronić I, Srdoč D, Horvatinčić N. 1986. Environmental ${ }^{14} \mathrm{C}$ levels around the $632 \mathrm{MWe}$ nuclear power plant Krsko in Yugoslavia. Radiocarbon 28(2A):644-8.

Otlet RL, Walker AJ, Fulker MJ. 1990. Survey of the dispersion of ${ }^{14} \mathrm{C}$ in the vicinity of the UK reprocessing site at Sellafield. Radiocarbon 32(1):23-30.

Palstra SWL, Karstens U, Streurman HJ, Meijer HAJ. 2008. Wine ethanol ${ }^{14} \mathrm{C}$ as a tracer for fossil fuel $\mathrm{CO}_{2}$ emissions in Europe: measurements and model comparison. Journal of Geophysical Research 113(D21): D21305, doi:10.1029/2008JD010282.

Povinec P. 1972. Very low background proportional counter for tritium dating. Nuclear Instruments and Methods 101(3):613-4.

Povinec P. 1978. Multiwire proportional counters for low-level ${ }^{14} \mathrm{C}$ and ${ }^{3} \mathrm{H}$ measurements. Nuclear Instruments and Methods in Physics Research 156(3):4415.

Povinec P, Saro S, Chudy M, Seliga M. 1968. Rapid method of carbon-14 counting in atmospheric carbon dioxide. International Journal of Applied Radiation and Isotopes 19(12):877-81.

Povinec P, Šivo A, Chudy M. 1986a. Seasonal variations of anthropogenic radiocarbon in the atmosphere. $\mathrm{Nu}$ clear Instruments and Methods in Physics Research B 17(5-6):556-9.

Povinec P, Chudy M, Šivo A. 1986b. Anthropogenic radiocarbon: past, present and future. Radiocarbon 28(2A):668-72.

Povinec PP, Šivo A, Šimon J, Holy K, Chudy M, Richtáriková M, Morávek J. 2008. Impact of the Bohunice Nuclear Power Plant on atmospheric radiocarbon. Applied Radiation and Isotopes 66(11):1686-90.

Povinec PP, Chudy M, Šivo A, Šimon J, Holy K, Richtáriková M. 2009. Forty years of atmospheric radiocarbon monitoring around Bohunice nuclear power plant, Slovakia. Journal of Environmental Radioactivity 100(2):125-30.

Reimer PJ, Brown TA, Reimer RW. 2004: Discussion: reporting and calibration of post-bomb ${ }^{14} \mathrm{C}$ data. Radiocarbon 46(3):1299-304.

Roussel-Debet S, Gontier G, Siclet F, Fournier M. 2006. Distribution of carbon 14 in the terrestrial environment close to French nuclear power plants. Journal of Environmental Radioactivity 87(3):246-59.

Segl M, Levin I, Schoch-Fischer H, Münnich M, Kromer B, Tschiersch J, Münnich KO. 1983. Anthropogenic ${ }^{14} \mathrm{C}$ variations. Radiocarbon 25(2):583-92.

Stuiver M, Polach HA. 1977. Discussion: reporting of ${ }^{14} \mathrm{C}$ data. Radiocarbon 19(3):355-63.

Suess HE. 1955. Radiocarbon concentration in modern wood. Science 122(3166):415-7. 
Svetlik I, Molnár M, Svingor E, Futó I, Pintér T, Rulík P, Michálek V. 2006. Monitoring of atmospheric ${ }^{14} \mathrm{CO}_{2}$ in central European countries. Czechoslovak Journal of Physics 56D(4):291-7.

Svetlik I, Povinec PP, Molnár M, Meinhardt F, Michálek V, Simon J, Svingor E. 2010. Estimation of long-term trends in the tropospheric ${ }^{14} \mathrm{CO}_{2}$ activity concentration. Radiocarbon 52(2-3):815-22.

Uchrin G, Csaba E, Hertelendi E, Ormai P, Barnabas I. 1992. ${ }^{14} \mathrm{C}$ release from a Soviet-designed pressurized water reactor nuclear power plant. Health Physics 63: $651-5$.

Uchrin G, Hertelendi E, Volent G, Slávik O, Morávek J, Kobal I, Vokal B. $1998 .{ }^{14} \mathrm{C}$ measurements at PWRtype nuclear power plants in three middle European countries. Radiocarbon 40(1):439-46.

UNSCEAR (United Nations Scientific Committee on the Effects of Atomic Radiation). 2000. Exposures from natural and man-made sources of radiation. Report to the General Assembly 1. New York: United Nations.

Usačev S, Povinec P, Chudy M, Šeliga M. 1973. Bratislava radiocarbon measurements I. Radiocarbon 15(3):443-50.

Veres M, Uchrin G, Hertelendi E, Csaba E, Barnabás I, Ormai P. 1995. Concentration of radiocarbon and its chemical forms in gaseous effluents, environmental air, nuclear waste and primary water of a pressurized water reactor power plant in Hungary. Radiocarbon 37(2):497-504. 